\title{
Prasa warszawska jako źródło do dziejów oświaty zakopiańskiej II połowy XIX i początków XX stulecia
}

Nie będzie błędem stwierdzenie, iż w Zakopanem II połowy XIX stulecia zaistniały placówki, dzięki którym podtatrzańska miejscowość zajęła trwałe miejsce w historii polskiej oświaty. Efekty zaś ich działalności widoczne były poza granicami zaboru austriackiego. Należały do nich bezsprzecznie: najstarsza instytucja edukująca młodzież góralską, Szkoła Przemysłu Drzewnego oraz przeznaczone kształceniu płci żeńskiej - Szkoła Pracy Domowej Kobiet i Szkoła Koronkarska. Stąd też w pierwszej części niniejszego artykułu podjęto próbę przybliżenia ich funkcjonowania w oparciu o publikacje drukowane na łamach prasy stołecznej, stanowiącej cenne źródło historyczne ${ }^{1}$. Przedstawiciele środowiska dziennikarskiego stolicy dostrzegli także inicjatywy na polu oświaty, jakie dokonały się pod Giewontem w ostatnim czternastoleciu poprzedzającym wybuch I wojny światowej. Z zainteresowaniem prasy zaboru rosyjskiego spotkała się działalność Towarzystwa Wyższych Kursów Wakacyjnych. Zagadnieniu temu poświęcona została druga część artykułu.

Istniejącą od 1876 r. zakopiańską Szkołę Przemysłu Drzewnego publicysta „Tygodnika Powszechnego” zaliczył na początku lat osiemdziesiątych XIX stulecia do „najcelniejszych” tego typu placówek w Przedlitawii. Kształciła młodzież pochodzącą nie tylko z Podhala tatrzańskiego, lecz także z odległych stron Galicji. Uczniowie zajmowali się wyrobem różnego rodzaju drobnych przedmiotów:

* Mgr, doktorant, Uniwersytet Jana Kochanowskiego w Kielcach.

1 Przyjęte ramy chronologiczne to szczególny okres w dziejach dziennikarstwa warszawskiego. Charakteryzował go, po pierwsze, ilościowy i jakościowy rozwój czasopiśmiennictwa na niespotykaną wcześniej skalę. Po drugie, istotne znaczenie miała sytuacja polityczna. W zaborze rosyjskim, wobec zakazu funkcjonowania instytucji przedstawicielskich i organizacji politycznych, prasa stała się głównym organem kształtującym i wyrażającym opinię publiczną. Patrz: W. G i e łż y ń s k i, Prasa warszawska 1661-1914, Warszawa 1992; Z. K m i e c i k, Prasa warszawska w okresie pozytywizmu (1864-1885), Warszawa 1971; t e n ż e, Prasa warszawska w latach 1886-1904, Warszawa 1989; H. M a rk i e w i c z, Pozytywizm, Warszawa 1978. 
ozdobnych pudełek, szachów i warcabów, fajek, cygarnic, igielników, ciupag, lasek alpejskich, używając materiałów z lipy, jesionu, kosodrzewiny. Wyroby te, z widoczną cechą miejscową, znajdowały niemały popyt także poza Zakopanem i Nowym Targiem. Istotne znaczenie dla rozwoju szkoły miało objęcie jej kierownictwa przez Franciszka Neużila - zdolnego i sumiennego nauczyciela, stawiającego sobie za cel przygotowanie fachowych, zdolnych rękodzielników². Pod jego kierunkiem uczniowie zapoznawali się z rysunkiem i modelowaniem z gliny. Wychowankowie, poza nabywanym w szkole wykształceniem technicznym i artystycznym smakiem, zyskiwali możliwość zapewnienia sobie niezależnej egzystencji. Każdy z nich miał książeczkę zarobkową, w której zapisywany był wykonany przedmiot wraz z kwotą otrzymaną ze sprzedaży ${ }^{3}$.

Uwagę poświęciła placówce także „Gazeta Warszawska”. Powołana celem wskrzeszenia przemysłu domowego na Podhalu, przybrała w początkach lat osiemdziesiątych XIX w. coraz bardziej widoczny charakter szkoły krajowej. Według danych pisma (1883 r.), na 44 uczniów 34 pochodziło z powiatu nowotarskiego, 2 z krakowskiego, po 1 z nowosądeckiego, wielickiego, brzeżanowskiego, ropczyckiego, nadworniańskiego, jarosławskiego, krośnieńskiego, 1 z Bawarii ${ }^{4}$.

W innej publikacji dziennik podkreślił, iż założenie szkoły było trafną, praktyczną i owocną inicjatywą. Szybki wzrost liczby wychowanków placówki (w 1879 r. - 16 uczniów; w 1884/1885 - przeszło 70) świadczył o potrzebie jej zaistnienia, a zarazem o rosnącym rozgłosie i poważaniu. Siedziba, jaką zajmowała - obszerny, widny i doskonale przewietrzany drewniany budynek, wzniesiony niewielkim kosztem około 6000 złotych reńskich - mogła stanowić przedmiot zazdrości niejednej instytucji oświatowej Królestwa Polskiego. Oprócz stolarzy, cieśli i budowniczych wiejskich, szkoła kształciła przede wszystkim snycerzy w drewnie. Czteroletni program obejmował następujące zajęcia teoretyczne: rysunki odręczne w zakresie elementarnym; rysunek linearny, ornamentalny, architektoniczny

${ }^{2}$ Franciszek Neużil (1845-1899); rzeźbiarz, nauczyciel, autor podręczników. Przeniesiony służbowo do Zakopanego w 1878, pełnił funkcję kierownika, a w latach 1886-1896 dyrektora Szkoły Przemysłu Drzewnego. W placówce uczył także rysunków zawodowych i odręcznych, snycerstwa i stolarstwa. Uruchomione przez niego przyszkolne warsztaty stały się zalążkiem przemysłu pamiątkarskiego w Zakopanem. Projektował domy w stylu tyrolskim, meble i ołtarze. Za jego sprawą w pracach szkoły dominowały motywy szwajcarskie i tyrolskie, jednocześnie pomijano sztukę rodzimą. Zarzucano mu także personalne i artystyczne germanizowanie szkoły. Należy jednak pamiętać, że właśnie pod kierunkiem Neużila placówka wykonała meble, uznane za pierwociny stylu zakopiańskiego. Patrz: M. P in k wa rt, L. D ł u g o łę c k a-P in k wa r t, Zakopane: przewodnik historyczny, Bielsko-Biała 2005, s. 44.

${ }^{3}$ J. C h o d o r o w i c z, Z gór i dolin, „Tygodnik Powszechny” 1882, nr 4, s. 60-61. Co ciekawe, redaktor w powyższej publikacji sportretował wychowanków placówki, podkreślając jednocześnie zasługi jej kierownika: „Ubogie, bose [...] lecz schludnie i czysto [...] odziane chłopięta, nader sympatycznie się nam przedstawiły. [...] pogodne, zdrowiem tryskające i swobodą młodociane ich twarzyczki, niekłamanem są chyba świadectwem wewnętrznego zadowolenia i czasu korzystnie spędzonego w Szkole. Od 12-to letnich [...] dzieciaków, do 17-to letnich wyrostków, wszyscy [...] pisać zaledwie i czytać umieją - mimo to [...] wyraz budzącej się inteligencyi świeci im z czoła. [...] grzeczność i pewna łatwość w obejściu [...] zaszczyt przynoszą niestrudzonemu przewodnikowi młodzieży, co spośród nędznych kolib [...] prostaczków en bloc przyjmując [...] umiejętnem postępowaniem, w przyjemnych [...] przekształcił chłopców".

${ }^{4}$ Wiadomości bieżące zagraniczne, „Gazeta Warszawska” 1883, nr 40, s. 2. 
oraz fachowy (rzeźbiarski, stolarski, tokarski). Ponadto naukę rzutów, cieniów i perspektywę oraz arytmetykę, geometrię, wiadomości technologiczne i prowadzenie ksiąg. Zajęcia teoretyczne wraz z pracą praktyczną trwały dziesięć godzin dziennie. Najwyższy zarobek dochodził do 6 guldenów tygodniowo, najniższy, początkującego ucznia, wynosił 50 centów ${ }^{5}$.

Co istotne, w szkole wytwarzano coraz większą liczbę mebli. Choć proste, były tańsze od produktów stołecznych, cechowały się przy tym brakiem jednostajności i pospolitości ${ }^{6}$.

Z krytyką placówki wystąpił natomiast Stanisław Witkiewicz, jedna z najważniejszych postaci Zakopanego swoich czasów ${ }^{7}$. Zdaniem autora cyklu Na Przełęczy, opublikowanego w „Tygodniku Ilustrowanym” w latach 1889-1890, stanowiła w Zakopanem „rozsadnik tyrolsko-wiedeńskiego gustu”. Doskonale prowadzona pod względem fachowym, odznaczała się jednocześnie nadzwyczajnym brakiem pomysłowości oraz inicjatywy. Nie ułatwiała w jakikolwiek sposób rozwoju miejscowych motywów artystycznych, tym samym nie spełniała swego zadania, polegającego na rozwinięciu sztuki stosowanej do rzemiosła. Wprowadzała formy niemieckie, renesansowe, w tym często niefortunne pomysły ozdób. W szkole brakowało nauczyciela-Polaka, zaś przy całej (godnej uznania) sumienności i wzorowym nauczaniu, od cudzoziemskiej kadry trudno było wymagać upodobania do „naszych” form artystycznych i chęci ich rozpowszechniania8.

Głos w powyższej kwestii zabrał także w obszernym, zawierającym bogate dane statystyczne, artykule opublikowanym na łamach „Wisły” w 1891 r. adwokat Leopold Meyet ${ }^{9}$. W jego przekonaniu, placówka należycie spełniała powierzone jej zadanie - kształcenie bezrolnych i bezdomnych górali, podniesienie przez naukę i pracę ich poziomu umysłowego i moralnego, połączone z moźliwością zarobku. Sprawozdanie z działalności instytucji za rok 1889/1890 dowodziło, że wyzwoliła na praktykę 103 uczniów. Pracowali oni w różnych kierunkach nie

${ }^{5}$ Dwie szkoły w Tatrach (w Zakopanem), „Gazeta Warszawska” 1886, nr 125, s. 1-2.

6 Tamże, nr 126, s. 1.

7 Stanisław Witkiewicz (1851-1915); malarz, prozaik, publicysta, krytyk artystyczny, działacz społeczny, twórca stylu zakopiańskiego. W Zakopanem był po raz pierwszy w 1876, od 1886 przyjeżdżał tu corocznie w celach leczniczych, w okresie 1890-1908 przebywał stale. Od 1886 znaczna część jego twórczości pisarskiej związana jest z Tatrami i Podhalem. Gorący propagator podhalańskiego zdobnictwa i budownictwa ludowego, na podstawie których stworzył tzw. styl zakopiański, zwany też podhalańskim i witkiewiczowskim. Autor projektów budowli w tym stylu, wzniesionych także poza Zakopanem, ponadto mebli, innych sprzętów i porcelany. Jego wpływ na stosunek społeczeństwa polskiego do Tatr i Podhala był ogromny. Zainteresowanie tym obszarem zostało jego działalnością pisarską utrwalone, pogłębione oraz rozszerzone na różne zagadnienia związane z regionem. Patrz: W. N o w a k o w s k a, Stanisław Witkiewicz - teoretyk sztuki, Wrocław 1970; H. K u r c z a b, Tatrzańska twórczość literacka Stanisława Witkiewicza, Rzeszów 1973; J. M a j d a, Góralszczyzna w twórczości Stanisława Witkiewicza, Wrocław 1979; Z. P y t e I, Witkiewiczowska architektura sakralna w Zakopanem, Zakopane 1999; B. To n d o s, Styl zakopiański i zakopiańszczyzna, Wrocław 2004; A. P y c k a, Kreacje i poglądy Stanisława Witkiewicza na tle głosów epoki, Kraków 2010.

8 S. W i t k i e w i c z, Na przełęczy, „Tygodnik llustrowany” 1889, nr 318, s. 68-69.

9 Leopold Meyet (1849 lub 1850-1912); literat, publicysta, współredaktor „Niwy” i „Świtu”, kolekcjoner dzieł sztuki. Prowadził ogromną korespondencję z wybitnymi pisarzami, m.in. z Marią Konopnicką i Elizą Orzeszkową, pośrednicząc bezinteresownie w ich kontaktach literacko-wydawniczych. Patrz: E. J a n k o w s k i, Meyet Leopold, [w]: PSB, t 20, s. 483-484. 
tylko w Zakopanem, lecz także w Krakowie, Lwowie oraz w innych miejscowościach Galicji ${ }^{10}$.

W omawianym roku szkoła miała osiem oddziałów z czteroletnim okresem nauki. Obejmowały one: 1) rzeźbiarstwo figuralne; 2) rzeźbiarstwo ornamentacyjne; 3) stolarstwo meblowe; 4) stolarstwo budowlane i przemysłu domowego; 5) ciesielstwo; 6) tokarstwo i jeden rok stolarstwa; 7) snycerstwo ornamentacyjne i figuralne przemysłu domowego; 8) snycerstwo i tokarstwo przemysłu domowego ${ }^{11}$.

Liczba wychowanków placówki zwiększała się stale. W roku 1889/1890 wynosiła 98 uczniów, z czego 65 to synowie rolników, 13 - urzędników, 4 - wyrobników, zaś reszta - dzieci rzemieślników. Kadra wraz z dyrektorem obejmowała 15 osób. Płaca nauczycieli stanowiła poważną pozycję w rubryce wydatków, wynosząc 13390 złotych reńskich rocznie. Szkoła otrzymywała dofinansowanie od Ministerstwa Wyznań Religijnych i Oświecenia Publicznego (15 100 złotych reńskich) oraz od wydziału krajowego we Lwowie (1500 złotych reńskich). Gmach stanowił własność Towarzystwa Tatrzańskiego, które pokrywało w dalszym ciągu wydatki na utrzymanie lokali szkolnych, światło i opał'².

W przeświadczeniu publicysty, szkoła, kształcąc odpowiednią liczbę rzeźbiarzy ornamentacyjnych i figuralnych, mogła wpłynąć na usunięcie z kościołów wiejskich nierzadko „wstrętnych” posągów ukazujących świętych, zaszczepić też lepszy gust i wymagania w zakresie budowy ołtarzy. W kierunku tym wykonano już zresztą kilka poważnych prac: ołtarz w stylu romańsko-ruskim do kaplicy zamkowej w Rudniku, ołtarz wielki i boczny w stylu gotyckim do kościoła parafialnego w Chochołowie oraz przedmioty $z$ drewna dębowego i figury przeznaczone dla świątyni w Buczniowie koło Tarnopola. Coraz piękniejsze prace wykonywano w stylu zakopiańskim. Dowodziły tego meble dla hr. Artura Potockiego ${ }^{13} z$ limby, wykładane drewnem gruszkowym, z okuciem żelaznym oraz przeznaczone do dwóch sypialni $-z$ drewna dębowego i jaworowego ${ }^{14}$. Na wyróżnienie zasługiwały też meble dębowe, wysłane w 1889 r. przez zakopiańską placówkę na wystawę przemysłową w Wiedniu. Ich oryginalność polegała zarówno na zdobnictwie, jak i na konstrukcji, pozostających ze sobą w związku. Wspomniane wyroby redaktor charakteryzował następująco:

Ozdobą są kwiaty i inne rysunki ze sprzętów góralskich w lekkiej płaskorzeźbie na gładkiem tle, pomalowane niebieską, czerwoną i szarą farbą. Skutkiem [...] i najgłówniejsze części składowe mebli są pod względem konstrukcji płaskie, nieozdobione wypukłorzeźbą, więc [...] nie bardzo wyskakujące w profilach. Tą [...] prostotą [...] wywołują efekt prawdziwy ${ }^{15}$.

${ }^{10}$ L. M e y e t, Kilka słów o szkołach zawodowych w Zakopanem, „Wisła” 1891, z. 2, s. 272.

${ }^{11}$ Tamże, s. 268-269

12 Tamże, s. 269.

${ }^{13}$ Artur Potocki (1850-1890); konserwatywny polityk galicyjski. Cieszył się opinią wzorowego gospodarza. Jego dobra składały się z czterech kompleksów: Krzeszowice z przyległościami w powiecie Chrzanowskim, Mędrzechów w Tarnowskiem, Staszów w Królestwie Polskim oraz Biała Cerkiew na Ukrainie. Od 1875 był jednym ze współwłaścicieli krakowskiego „Czasu”. W tymże roku rozpoczął także działalność publiczną. W 1883 poseł do Sejmu Krajowego. Miał udział w zarządach licznych organizacji i instytucji, m.in. w latach 1887-1889 prezes Towarzystwa Rolniczego w Krakowie. Patrz: J. Z d r a d a, Potocki Artur, [w:] PSB, t. 27, s. 797-799.

${ }^{14}$ L. M e y e t, Kilka słów... s. 273-274.

15 Tamże, s. 274-275. 
Publikacje dotyczące działalności placówki, a zwłaszcza jej kadry kierowniczej, odnaleźć można na łamach prasy warszawskiej także w początkach XX stulecia. Głos w tej kwestii zabrał Antoni Chołoniewski ${ }^{16}$, autor artykułów dotyczących Tatr i Zakopanego drukowanych na łamach „Biesiady Literackiej”.

Publicysta zwrócił uwagę na działalność drugiego dyrektora szkoły, Edgara Kovatsa ${ }^{17}$. Uznawał on artystyczną wartość motywów zakopiańskich, ale utrzymywał, iż są zbyt ubogie, by można je było rozwinąć w „styl odrębny”. Wprowadził, co prawda, zakopiańszczyznę do szkoły, zastosował ją wszechstronnie, ale podporządkował jednocześnie własnej fantazji artystycznej. Takie działanie wywołało protesty. Przeciwnicy utrzymywali, „że żywotność motywów zakopiańskich jest daleko większa, aniżeli się Kovatsowi wydaje i że artyście nie wolno zbaczać od nich pod grozą zepsucia stylu"18.

Choć kierownik placówki był niewątpliwie postacią kontrowersyjną, nie należało jednak zapominać o jego zasługach. Oddany swej pracy twórca, zapewnił szkole rozkwit, umiał zainteresować kiełkującą sztuką podhalańską szerokie kręgi odbiorców. Wykształcił zastęp zdolnych robotników, a nawet artystów „czystej wody". Po raz pierwszy za jego kierownictwa komponowane w duchu zakopiańskim ołtarze zaczęły zdobić kościoły w odległych okolicach kraju, a meble wytwarzane prawie wyłącznie na podstawie rysunków artysty przestały być rzadkością w zamożnych polskich domach ${ }^{19}$.

Działalność Szkoły Przemysłu Drzewnego, zajmującej szczególne miejsce w rozwoju sztuki podhalańskiej, ocenił jeden z jej nauczycieli, Władysław Skoczylas ${ }^{20}$. Zjawiskiem odbijającym się negatywnie na funkcjonowaniu placówki

${ }^{16}$ Antoni Chołoniewski (1872-1924); dziennikarz i publicysta. Już jako gimnazjalista pisywał korespondencje ze Stryja i Podkarpacia do gazet Iwowskich. Praktykę dziennikarską odbył we Iwowskim „Przeglądzie”. Współpracował m.in. ze „Słowem Polskim”, gdzie objął dział kultury i spraw ogólnonarodowych. Równocześnie pisał korespondencje z Galicji do petersburskiego „Kraju”. W 1903 przeniósł się do Krakowa, gdzie objął (1905) kierownictwo filii redakcji i administracji warszawskiego dwutygodnika „Świat”. Podjął żarliwą obronę polskości na kresach zachodnich. Patrz: L. Z a k u I s k i, Chołoniewski Myszka Antoni, [w:] PSB, t. 3, s. 406-408.

17 Edgar Kovats (1849-1912); architekt, malarz, pisarz, dyrektor placówki w latach 1896-1900. Rozwinął aktywną działalność w propagowaniu form architektonicznych, zwłaszcza zdobniczych, opartych na swoistej stylizacji motywów, którą nazwał „sposobem zakopiańskim”. W 1899 r. ogłosił publikację o powyższym tytule, przeciwstawiając się tym samym istnieniu stylu zakopiańskiego. Jego poglądy artystyczne wywołały ostrą polemikę, zwłaszcza na łamach prasy Iwowskiej. Patrz: I. Try b o w s k i, Kovats Edgar, [w:] PSB, t. 14, s. 508-509.

${ }^{18}$ A. C h o ł o n i e w s k i, Spór o chatę polską, „Biesiada Literacka” 1901, nr 31, s. 94.

19 Tamże, s. 94. W tej publikacji redaktor zawarł także ogólną refleksję dotyczącą instytucji. W przeświadczeniu Chołoniewskiego stanowiła ognisko powołane do tego, „aby w najdalsze strony wysyłać promienie sztuki zakopiańskiej ornamentalnej i budowniczej [...]. Żywotność jej została od dawna udowodniona. Na 22 szkół przemysłu drzewnego w Przedlitawii szczyci się największą liczbą uczniów, która w roku ubiegłym wynosiła 107. Liczba ta powinna wymowniej, aniżeli jakakolwiek argumentacya, skłonić do najgorliwszego zaopiekowania się dalszemi losami szkoły zakopiańskiej [...]".

20 Władysław Skoczylas (1883-1934); wybitny grafik, malarz i rzeźbiarz, inicjator i twórca nowoczesnego drzeworytu artystycznego w Polsce. W latach 1908-1918 był z przerwami nauczycielem rzeźby figuralnej w zakopiańskiej Szkole Przemysłu Drzewnego. Pobyt w Zakopanem odegrał dużą rolę w kształtowaniu się jego twórczości. Autor m.in. licznych drzeworytów o tematyce podhalańskiej, tatrzańskiej i orawskiej. Patrz: M. G r o ń s k a, Władysław Skoczylas, Wrocław 1966. 
była cudzoziemska kadra kierownicza, nie potrafiąca zrozumieć i odczuć uroku tkwiącego w twórczości góralskiej. Pierwszy dyrektor, Franciszek Neużil był niewątpliwie doskonałym administratorem, jednak jego projekty oparte na motywach ludowych wykazywały tendencję do "renesansowania” zakopiańszczyzny. Jedynie przy zastosowaniu samego ornamentu pozostawał wierny jego charakterowi. Z kolei projekty wnętrz, ołtarzy i mebli następcy Czecha, Edwarda Kovatsa, choć bazujące w szczegółach na motywach ludowych, nie oddawały w całości kolorytu podhalańskiego, odpowiadając raczej stylowi arabskiemu. Poza tym Kovats używał do ornamentacji polichromii i złoceń, kłócących się ze sztuką góralską. Dopiero trzeci dyrektor szkoły, Stanisław Barabasz, nadał meblarstwu podhalańskiemu odpowiednie formy ${ }^{21}$. Jego meble odznaczały się logiką, wygodą architektoniczną i zmodernizowaniem form góralskich do użytku praktycznego ${ }^{22}$.

Poza Szkołą Przemysłu Drzewnego, szkolnictwo zakopiańskie reprezentowały także placówki powstałe celem edukacji płci pięknej. Publicystka i powieściopisarka Zofia Urbanowska ${ }^{23}$ zwróciła w swych korespondencjach spod Giewontu uwagę na Szkołę Pracy Domowej Kobiet - prowadzoną przez hrabinę Zamoyską, matkę nabywcy Zakopanego. W opinii piszącej, szkoła była mało znana, zwłaszcza w Królestwie. Urbanowska przybliżyła czytelnikom program instytucji, która przyjmowała uczennice, mające w przyszłości pełnić obowiązki gospodyń, pokojówek i służących. Otwierała swe mury także dla dziewcząt po skończonej edukacji domowej lub elementarnej celem zapoznania ich z szeroko pojmowanym praktycznym gospodarstwem kobiecym. Wreszcie, organizowała co najmniej roczną praktykę dla zamożniejszych panien. Warunki przyjęcia, w zależności od stopnia zamożności, były niejednolite. Miesięczny koszt utrzymania wynosił od 10 do 45 złotych reńskich. Jedyny w swoim rodzaju zakład gromadzący w 1890 r. około 80 wychowanek wzbudzał duże zainteresowanie przebywających w Zakopanem gości ${ }^{24}$.

W dalszej części artykułu publicystka podkreślała:

${ }^{21}$ Stanisław Barabasz (1857-1949); malarz, architekt, pedagog, pionier narciarstwa polskiego, myśliwy. Od 1877 r. często przebywał w Zakopanem i wyprawiał się w Tatry. W 1901 r. objął kierownictwo Szkoły Przemysłu Drzewnego, pozostając na tym stanowisku przez 21 lat. Miał duże zasługi w rozwoju placówki, wprowadzając podhalańskie formy zdobnicze, oparte na ludowych wzorach. Patrz: Stanisław Barabasz, [w:] Wielka encyklopedia tatrzańska, red. Z. i W. H. Paryscy, Poronin 1995, s. 50-51.

22 W. S k o c z y l a s, Sztuka na Podhalu (2), „Ziemia” 1911, nr 23, s. 377-378.

${ }^{23}$ Zofia Urbanowska (1849-1939); współpracowała z „Gazetą Polską”, „Przeglądem Tygodniowym”, była członkiem kolegium redakcyjnego „Przeglądu Pedagogicznego”. Autorka głośnych w swoim czasie i wielokrotnie wydawanych powieści dla młodzieży. Przez kilkanaście lat jeździła do Zakopanego, zapoznając się wszechstronnie z Podhalem i Tatrami. Rezultatem tych zainteresowań stała się powieść Róża bez kolców (wyd. książkowe Warszawa 1903, Lwów 1928 i Warszawa 1958). Książka ta pozostaje klasyczną pozycją w literaturze tatrzańskiej. Patrz: K. K u l i c z k o w s k a, Urbanowska Zofia, [w:] Literatura polska, red. J. Krzyżanowski, t. 2, Warszawa 1985, s. 531.

${ }^{24}$ Z. U rbanowska, Korespondencya z Zakopanego, „Kronika Rodzinna” 1890, nr 20, s. 631-632. 
Przewodniczka zakładu wraz z córką, nauczycielkami i kapelanem, szczerze mu są poświęcone; nie jest to więc bynajmniej pańska zabawka, ale szlachetne obywatelstwo, świadomość potrzeby społecznej i mozół. Na owoce tej instytucji, jedynej dotąd u nas, trzeba czekać czas jakiś ${ }^{25}$.

Ukryta w leśnym gąszczu Kuźnic instytucja hrabiny Zamoyskiej stała się tematem publikacji „Wędrowca”. Stanowiła, jak podkreśliła redakcja, zakład pracy domowej i gospodarstwa kobiecego w ścisłym znaczeniu. Nauka odbywała się w ramach trzech oddziałów. Pierwszy przeznaczony był dla uczennic pochodzących z zamożnych domów, mających zapewniony byt. Godziny ranne poświęcone były zajęciom w kuchni, mleczarni, piekarni, spiżarni, pralni i gospodarstwie podwórzowym, popołudniowe zaś - lekturze dzieł poważniejszej treści, muzyce, nauce języków obcych, nauce szycia, haftu, kroju, religii, rachunkowości gospodarczej itp. Opłata za kształcenie i utrzymanie wynosiła 50 złotych reńskich ${ }^{26}$.

Kształcenie w drugim oddziale trwało od jednego do trzech lat, utrzymanie zaś miesięczne kosztowało 25 złotych reńskich. Dziewczęta, stosownie do woli rodziców (opiekunów), wykonywały czynności gospodarskie przez cały dzień lub tylko w godzinach rannych. Pozostały czas, podobnie jak w oddziale pierwszym, przeznaczony był na nauki uzupełniające i „,pracę nad talentami”27.

Możliwość pobierania nauki w oddziale trzecim uwarunkowana była posiadaniem świadectwa lekarskiego, stwierdzającego odpowiedni zasób sił do wykonywania pracy fizycznej. Oddział ten obejmował przeważnie dziewczęta niezamożne, stąd system pobieranej nauki był tak pomyślany, „aby [...] w każdej gałęzi wykładanych umiejętności doszły do pewnej wprawy”. Uczennice zaznajamiały się z kucharstwem, piekarstwem, mleczarstwem, prowadzeniem gospodarstwa w spiżarniach, piwnicach, oborze, chlewach i kurnikach, uczyły się prania, maglowania, prasowania, szycia, haftu, cerowania, krawiectwa i gorseciarstwa. Oprócz wymienionych przedmiotów miały także okazję zapoznać się z ogrodnictwem warzywnym, funkcjonowaniem apteki, introligatorstwem oraz szewstwem. Poświęcały kilka godzin tygodniowo nauce religii, rachunków, a także śpiewu i rysunków - w zależności od predyspozycji. Opłata za utrzymanie wynosiła 10 złotych reńskich miesięcznie ${ }^{28}$.

Termin wstąpienia do zakładu nie był określony, ściśle przestrzegano natomiast kryterium wieku: do pierwszego i drugiego oddziału przyjmowano dziewczęta po ukończeniu lat 16 , do trzeciego - między 14 a 18 rokiem życia ${ }^{29}$.

Redakcja, zapoznawszy czytelników z programem placówki, pisała w końcowym fragmencie publikacji:

Jednym z ważnych czynników moralnych jest rygor [...]. Pomimo ścisłej kontroli i troskliwej opieki, uczennice muszą się ściśle stosować do regulaminu ogólnego i specyalnych przepisów odpowiednich do pracy, której się [...] oddają. W ten sposób [...] przyzwyczajają się czuwać nad sobą, pilnować się [...], czem bezwiednie z dzieci przemieniają się w kobiety myślące, stojące siłą wyrobionego charakteru na straży [...] przyszłych obowiązków ${ }^{30}$.

\footnotetext{
25 Tamże, s. 632.

${ }^{26}$ M o n t a n u s, Szkoła gospodarstwa kobiecego w Zakopanem, „Wędrowiec” 1896, nr 46, s. 381.

27 Tamże.

28 Tamże.

29 Tamże.

30 Tamże, s. 382.
} 
Zakład ufundowany przez generałową Zamoyską, umożliwiający zdobycie teoretycznych i praktycznych wiadomości dotyczących "wszelkich zakresów” gospodarstwa kobiecego, wzbudzał niejednokrotnie zainteresowanie tygodnika "Bluszcz”. Co szczególnie istotne - zakopiańskie „Kuźnice” umożliwiały wzajemne zbliżenie dziewcząt pochodzących zarówno z wyższych, jak i niższych warstw społecznych; ścisłe - co zaobserwował anonimowy korespondent - zbratanie osób inteligentnych i wykształconych z przedstawicielkami szarego tłumu. Ten specyficzny kontakt miał na celu realny pożytek społeczny - skierowanie kobiet ze wszystkich sfer ku umiejętnej i odpowiadającej stanowisku każdej z nich pracy w rodzinie i poza nią ${ }^{31}$.

Przeznaczony dla kobiet tygodnik ilustrowany szczegółowo scharakteryzował zakład kuźnicki w 1905 r. W mury placówki wstępowało corocznie około 50 nowych uczennic. Najwięcej z nich pochodziło z Galicji, Litwy, Żmudzi i Białorusi. We wspomnianym roku zakład kształcił około 150 dziewcząt w ramach trzech oddziałów. Koszt nauki wynosił odpowiednio 1200, 720 i 240 koron rocznie. Znaczna część wychowanek trzeciego oddziału, należąca do różnych sfer społecznych, pobierała nauki bezpłatnie ( $z$ wyjątkiem opłaty na ubranie wynoszącej 50 koron rocznie) $)^{32}$.

W początkach $X X$ stulecia program obejmował następujące nauki praktyczne: 1) usługa przy stole i kredensie - miesiąc; 2) lampiarnia - 2 tygodnie; 3) mleczarnia - miesiąc; 4) piekarnia - miesiąc; 5) kuchnia czeladnia - miesiąc; 6) kuchnia pańska - 2 miesiące; 7) spiżarnia, obejmująca piwnicę, przechowywanie jarzyn, owoców itp. - 2 miesiące; 8) obsługa apteki i chorych - miesiąc; 9) pralnia i prasowalnia - 6 miesięcy; 10) szwalnia: krój i naprawa bielizny ozdobnej na zamówienie, naprawa koronek, dywanów, krój i szycie okryć i sukien - 18 miesięcy; 11) porządki domowe - miesiąc; 12) gospodarstwo folwarczne, czyli zajęcia przy bydle, trzodzie i drobiu - 2 miesiące; 13) ogrodnictwo, głównie uprawa warzyw i ziół leczniczych w przerwach między innymi zajęciami; 14) prowadzenie ksiąg handlowych i kasy; 15) sklepikarstwo, a więc kupno hurtowe i sprzedaż detaliczna materiałów piśmiennych, książek, przyborów do szycia itp.; 16) introligatorstwo ${ }^{33}$.

Edukację uzupełniały wykłady poobiednie, nie zawsze odbywające się regularnie, obejmujące buchalterię, arytmetykę oraz śpiew chóralny. Ważne miejsce zajmowały w nich także historia powszechna i Polski. W procesie dydaktycznym udział brała generałowa Zamoyska, prowadząc dwa razy w tygodniu prelekcje o obowiązkach kobiety, o wychowaniu według zasad katechizmu oraz zachowaniu się w zakładzie i poza nim ${ }^{34}$. Duże znaczenie przywiązywano do odpowiedniego doboru lektur ${ }^{35}$.

31 J.T., Z listów do „Bluszczu”, „Bluszcz” 1902, nr 37, s. 441.

32 Ks. W. K i r c h n e r, Praca społeczna kobiet w Galicji, „Bluszcz” 1905, nr 1, s. 6-7.

${ }^{33}$ Tamże, s. 7-8.

${ }^{34}$ Redaktor podkreślił: „Pani Z. tak się zżyła z zakładem, a zakład tak z jej życia powstał, tak przez nią zorganizował się i z niej wyrósł, że [...] jest jej organizmem, dalszem upostaciowaniem się jej ducha".

${ }^{35}$ Ks. W. K i r c h n e r, Praca społeczna..., „Bluszcz” 1905, nr 2, s. 18. 
Budynek zakładu przedstawiał się nadzwyczaj skromnie. Pozbawiony był nowoczesnych wygód, jak choćby centralnego ogrzewania. Wszystko, począwszy od kuchni aż do prywatnych pokojów generałowej, cechowała prostota. Każdy oddział posiadał osobny dormitraż i pokój jadalny. Oddzielne, niewielkie pomieszczenia przeznaczono na bibliotekę, introligatornię, lampiarnię, aptekę, naprawę pościeli i mebli oraz przechowywanie bielizny. Zakład dysponował piernikarnią i piekarnią zaopatrującą m.in. restaurację kuźnicką, mieszczącą się przy drodze na Kalatówki, sklep z materiałami piśmienniczymi i przyborami do szycia oraz obszerną szwalnię. W dolnej części budynku mieściła się kaplica i dużych rozmiarów sala wykładowa ${ }^{36}$.

Do ujemnych stron należało zaliczyć niewielką w stosunku do przyjętego zakresu działania liczbę współpracowników (około 20 nauczycielek) oraz brak specjalistów. Uniemożliwiał on rozszerzenie działalności zarobkowej placówki. Jej wyroby gastronomiczne (pierniki, ciastka) oraz środki higieny (mydła, kuźnicka woda kolońska), choć chętnie nabywane przez zwiedzających gości, nie spełniały oczekiwań. Niski był poziom rozwoju hodowli drobiu, a także uzależnionych od miejscowych warunków sadownictwa, warzywnictwa i pszczelarstwa ${ }^{37}$.

Instytucja, przypominająca niewielki dwór szlachecki, łączyła staropolską tradycję z nowoczesnym sposobem pojmowania obowiązków kobiety. W opinii publicysty ustępowała pierwszeństwa nowszym placówkom, m.in. założonej w Chyliczkach przez Cecylię Plater-Zyberk ${ }^{38}$. Nie umniejszało to jednak jej pionierskiego charakteru i spełnianej roli:

Kto rozumie [...] jak u nas jest zaniedbane wychowanie [...] w kierunku gospodarstwa domowego [...] jak dzisiejsze szkoły nie przygotowują do życia praktycznego, ten będzie życzył, aby zakład [...] jak najbardziej się rozwijał i aby jak najwięcej podobnych powstawało $[\ldots]^{39}$.

Na trzy lata przed wybuchem I wojny światowej w murach słynnego zakładu dla panien realizującego ideał polskiego wychowania narodowego przebywało 160 uczennic. Placówka składająca się z szeregu budynków jawiła się jako wielki i misterny mechanizm, którego poszczególne części składowe funkcjonowały bez zrzutu. Redakcja „Świata” podsumowała działalność drogocennej instytucji:

Wpływ Kuźnic wsiąknął już dobroczynnie w nasze życie. Bez wyjątku wszystkie dzielnice Polski pobierają odsetki od kapitału moralnego, jaki złożyła tu pani Zamoyska ${ }^{40}$.

${ }^{36}$ Ks. W. K i r c h n e r, Praca społeczna..., „Bluszcz” 1905, nr 3, s. 29.

37 Tamże, s. 29-30.

${ }^{38}$ Cecylia Plater-Zyberk (1853-1920); pedagog, działaczka społeczna, publicystka. Założyła w Warszawie szkołę rękodzielniczą dla dziewcząt, działającą w latach 1883-1908. Po śmierci fundatorki placówka przybrała jej imię. Ponadto w zakupionym przez siebie majątku Chyliczki pod Warszawą założyła w 1891 żeńską szkołę gospodarczą. Oba zakłady powstały w okresie największej rusyfikacji i utrzymanie polskiego charakteru placówek było wielką zasługą Plater -Zyberk. W ich urządzeniu wzorowała się na najlepszych szkołach europejskich. Współzałożycielka Katolickiego Związku Kobiet Polskich (1904). Autorka około 35 książek i broszur. Patrz: T. G ó r s k i, Plate-Zyberk Cecylia, [w:] PSB, t. 26, s. 693-694.

39 Tamże, s. 30.

${ }^{40}$ A.Ch., Właściciel Kuźnic, „Świat” 1911, nr 33, s. 10. 
Z uznaniem publicystów stołecznych spotkała się także inna zakopiańska instytucja kształcąca dziewczęta - Szkoła Koronkarska. Uwagę „Świtu” - ilustrowanego tygodnika dla kobiet - zwróciło ogłoszone po raz pierwszy w 1887 r. przez placówkę urzędowe sprawozdanie, obejmujące czteroletni okres istnienia szkoły, zawierające jej statut i plan nauk. Utwierdzało w przeświadczeniu redakcji o doskonałej organizacji, nadzorze i kierunku „ze wszech miar sympatycznej” i pożytecznej instytucji. Już w drugim roku funkcjonowania rozpoczęto wyrób koronek na sprzedaż. Cały zarobek, po odjęciu jedynie wartości materiału, przypadał uczennicom. Wypłacone im sumy za wyrobione koronki wynosiły: w roku 1884 408 złotych reńskich, w 1885 - 756, w 1886 (do listopada) - 1166. Z kolei wartość wykonanych koronek brutto wynosiła: w roku 1884 - 514 złotych reńskich, w 1885 - 1115, a w 1886 - 1460. Nie ulegało wątpliwości, że szkoła zakopiańska „[...] zręcznym i [...] uzdolnieniem umysłowem odznaczającym się góralkom zapewnia zarobek korzystny, zaprawiając je do pracy uczciwej i uszlachetniającej"11.

Intensywny rozwój, jaki przeżywała placówka w końcu lat osiemdziesiątych XIX stulecia dostrzegła również w swych korespondencjach z Zakopanego wspomniana już Zofia Urbanowska. Szkoła Koronkarska liczyła w 1889 r. około 40 uczennic. Jej wyroby obecne na różnych wystawach krakowskich, wiedeńskich i londyńskich, wszędzie zyskiwały „[...] uznanie, pokup i obstalunki”. Placówka nie poprzestawała na niewolniczym naśladownictwie znanych wzorów, dążyła do stworzenia nowych, na podstawie motywów miejscowych. Uwagę zwracały kołnierze i mankiety ułożone z szarotek i innych kwiatów tatrzańskich „Z wielkim smakiem”42.

Wskutek ciągłego i systematycznego rozwoju szkoła składała się w $1891 \mathrm{r}$. z dwóch oddziałów: „zawodowego” i „roboczego”. W pierwszym nauka trwała 3 lata i obejmowała przedmioty: rysunki elementarne, odręczne i geometryczne; rysunki koronek; naukę wyrobu koronek wszelkiego rodzaju. Oddział drugi ograniczał się do nauki wyrobu koronek i miał głównie na celu zręczność techniczną w ich fabrykacji. Oprócz tego wszystkie uczennice pobierały naukę uzupełniającą czytania, pisania, religii, arytmetyki, historii, prowadzenia ksiąg i rachunków handlowych ${ }^{43}$.

Poza dziewczętami uczącymi się systematycznie, w szkole przebywały także uczennice, kształcące się tylko przygodnie. Wszystkim udzielano nauki bezpłatnie, a ponadto Wydział Krajowy przyznawał stypendia po 2 i 5 złotych reńskich. Skorzystało z nich w roku 1886 pięć, w 1887 osiem, w 1888 dziesięć, w 1889 siedemnaście, a w 1890 dziesięć uczennic. Poza tym jedna z nich otrzymała 100 złotych reńskich rocznej zapomogi, a dwie zasiłek na dalsze kształcenie w odpowiednim instytucie wiedeńskim ${ }^{44}$.

$\mathrm{Na}$ utrzymanie szkoły Wydział Krajowy przeznaczał 2200 złotych reńskich. Z sumy tej opłacano koszt lokalu, pensję przełożonej i nauczycieli. Dochód, osią-

\footnotetext{
${ }^{41}$ Z domu i ze świata, „Świt” 1887, nr 147, s. 24.

${ }_{42}$ Z. U r b a n o w s k a, Korespondencya z Zakopanego (II), „Kronika Rodzinna” 1889, nr 18, s. 562.

${ }^{43}$ L. M e y e t, Kilka słów..., s. 253.

${ }^{44}$ Tamże, s. 253-254.
} 
gnięty ze sprzedaży wyrobów, po potrąceniu wydatków na utrzymanie placówki oraz dziesiątej części na fundusz żelazny, rozdzielano między uczennice. Co istotne, szkoła wykształciła wiele samodzielnych nauczycielek. Pracowały one w Muszynie, Wilnie, Królewcu, Kieżmarku, Wrocławiu, Mikulińcach, Pieniakach ${ }^{45}$.

Znaczny postęp w fabrykacji koronek szkoła zawdzięczała przede wszystkim swej znakomitej kierowniczce. Gruntownie wykształcona, obdarzona wieloma zaletami pedagogicznymi i zmysłem artystycznym, prowadziła powierzoną jej instytucję w sposób budzący uznanie pod każdym względem. Jej inicjatywie należało zawdzięczać wyrób koronek opartych na motywach czysto miejscowych. Pierwsze tego rodzaju próby, do tego „wcale udatne” zasługiwały niewątpliwie na uwagę. Do tego celu posłużyły m.in. szarotki obficie rosnące w Zakopanem i okolicy oraz wzory rzeźby, zdobiącej tzw. łyżniki - półeczki do zawieszania łyżek, znajdujące się w chatach góralskich ${ }^{46}$.

Spośród szeregu inicjatyw oświatowych, mających miejsce w Zakopanem w pierwszym czternastoleciu XX w., uwagę prasy stołecznej zwróciła instytucja o charakterze uniwersyteckim, rozpoczynająca działalność w sierpniu 1904 r., założona przez Towarzystwo Wyższych Kursów Wakacyjnych. Instytucja ta, jak informował czytelników „Wędrowiec”, stawiała sobie za zadanie podniesienie poziomu wiedzy i myśli krytycznej w społeczeństwie polskim za pomocą szeregu wykładów. Miały one nie tylko zaznajamiać z najnowszymi osiągnięciami nauki, lecz przede wszystkim przez zapoznanie z metodami badań naukowych i przez filozoficzne traktowanie każdego przedmiotu - pobudzić słuchaczy do samodzielnej pracy, pomóc w wyrabianiu światopoglądu i stworzyć w rezultacie atmosferę, „w której dojrzewają umysły”47.

Co istotne, periodyk zapoznał czytelników z programem kursów. Wykłady obejmowały następujące dziedziny: filozofię i nauki przyrodnicze ${ }^{48}$, językoznawstwo ${ }^{49}$, historię ${ }^{50}$, literaturę i sztukę ${ }^{51}$, ekonomię polityczną i socjologię ${ }^{52}$ oraz prawo ${ }^{53}$. Ponadto uczestnicy mieli okazję odbycia wycieczek geologicznych

45 Tamże, s. 254.

46 Tamże, s. 255.

47 Kronika bieżąca, „Wędrowiec” 1904, nr 17, s. 537.

${ }^{48} \mathrm{~L}$. Krzy wicki, Typy antropologiczne a związki etniczne (Zarys antropologii $i$ etnografii z uwzględnieniem etnografii polskiej); A. M a h r b u r g, Psychologia woli i Zagadnienia bytu i stawania się; K. T w a r d o w s k i, Główne prądy w filozofii wieku XIX.

${ }^{49} \mathrm{~J}$. B a u d o u in de Courte n a y, Psychologia języka ze szczególnym uwzględnieniem psychologii języka polskiego.

50 K. P o t k a ń s k i, O powstaniu państwa polskiego; W. Sobieski, Historia reformacji w Polsce; M. S o k o I n i c k i, Metody badań nad dziejami nowożytnymi.

51 P. C h m i e I o w s k i, O najwybitniejszych lirykach polskich doby najnowszej; W. F e I d m a n, Stefan Żeromski; A. G ó r s k i, O Mickiewiczu; J. K a s p r o w i c z, Romantyzm niemiecki; K. M okło w s k i, Dwutorowość naszej kultury artystycznej (Sztuka ludowa i sztuka stylów historycznych); S. W i t k i e w i c z, Sztuka w życiu narodowym.

52 Z. G o li ń s k a, Podstawy polityki społecznej; K. K r a u z, Nowoczesny ruch społeczny jako Drugie Odrodzenie; L. K r z y w i c k i, Psychologia życia zbiorowego.

53 S. P o s n e r, Główne prądy i zadania współczesnej filozofii prawa. 
pod kierunkiem Mieczysława Limanowskiego ${ }^{54}$ w połączeniu z prelekcją O powstawaniu gór (przykład: Tatry) ${ }^{55}$.

Porządek i kolejność wykładów oraz konwersatoriów miał podać szczegółowy program ogłoszony w maju 1904 r. Miał także zawierać krótką treść wykładów oraz odnośną literaturę, aby umożliwić słuchaczom przygotowanie się do prelekcji. Wpis na wszystkie wykłady wynosił 20 koron. Słuchacze Towarzystwa Wyższych Kursów Wakacyjnych otrzymywali po opłaceniu całego kursu legitymację zwalniającą od opłaty klimatycznej (12 koron od osoby) $)^{56}$.

Zdaniem redakcji „Gazety Polskiej”, utożsamianie nowej instytucji z uniwersytetem powszechnym bądź ludowym, popularyzującym wiedzę bez głębszych aspiracji naukowych było błędne. Kursy stawiające sobie za cel szerzenie kultu czystej nauki stanowiły podwalinę pod przyszły „uniwersytet wolny”, na wzór placówek tego typu istniejących w Paryżu i Brukseli. W dniu otwarcia liczyły ponad 380 słuchaczy ${ }^{57}$.

W kolejnej publikacji poświęconej Wyższym Kursom Wakacyjnym dziennik kontynuował rozważania dotyczące kierunku, jaki należało nadać nowo powstałej instytucji. W przeświadczeniu publicystów pisma, kursy powinny uzupełniać wiedzę, stanowić bodziec do studiów specjalistycznych, skupiać środowisko intelektualne, dawać wskazówki celem dalszego samokształcenia. Przedsięwzięcie, niewątpliwie pożyteczne, cieszyło się dużą popularnością. Na wykłady uczęszczało od 100 do 400 osób. Co istotne, Zakopane, w porównaniu z innymi wielkimi miastami, oferowało dobre warunki do nauki w porze letniej ${ }^{58}$.

O otwartych po raz pierwszy w Zakopanem Wyższych Kursach Wakacyjnych pisała w korespondencji opublikowanej w „Przeglądzie Tygodniowym” publicystka i malarka Zofia Skorobohata-Stankiewicz ${ }^{59}$. Przedsięwzięcie stanowiło dużą atrakcję i wywołało zainteresowanie szerokich kół inteligencji z Królestwa Polskiego, Galicji oraz Wielkiego Księstwa Poznańskiego. Już pierwsza seria wykładów, trwająca od 1 do 15 sierpnia, pozwoliła na wyciągnięcie pozytywnych wniosków co do dalszego kierunku kursów. Wykłady prowadziło siedmiu profesorów. Za tematy służyły różne gałęzie wiedzy, ze szczególnym uwzględnieniem nauk spo-

54 Mieczysław Limanowski (1876-1948); od 1898 przebywał w Zakopanem, prowadził badania własne jako współpracownik Muzeum Tatrzańskiego im. T. Chałubińskiego. Pierwsze artykuły geologiczne zamieszczał od 1899 w „Przeglądzie Zakopiańskim”, następnie w warszawskim „Wszechświecie” oraz w „Pamiętniku Towarzystwa Tatrzańskiego”. Jednocześnie w prasie zakopiańskiej i stołecznej pisał o tzw. stylu zakopiańskim, publikował recenzje teatralne, nowele i in. Wiele swych większych rozpraw, dotyczących Tatr, ogłosił w latach 1910-1913. Patrz: Z. J. W ó j c i k, Limanowski Mieczysław Bolesław Wincenty, [w:] PSB, t. 17, s. 346-348.

55 Kronika bieżąca, „Wędrowiec” 1904, nr 17, s. 537.

56 Tamże.

57 Dr K., Otwarcie wyższych kursów wakacyjnych w Zakopanem, „Gazeta Polska” 1904, nr 212, s. 1.

58 K. Ś w i t a, Wyższe Kursy Wakacyjne w Zakopanem, „Gazeta Polska” 1904, nr 248, s. 1.

59 Zofia Skorobohata-Stankiewicz (1871 - po 1938); autorka artykułów, esejów i broszur z zakresu estetyki życia codziennego, historii sztuki, krytyki artystycznej. W latach 1903-1914 współpracowała z „Bluszczem”, zamieszczając recenzje z wystaw, sylwetki i wspomnienia pośmiertne o malarzach i rzeźbiarzach. Ogłaszała także artykuły m.in. w „Przeglądzie Tygodniowym”, „Przeglądzie Powszechnym”, „Kulturze Polskiej”, „Biesiadzie Literackiej”, „Echu Literackim i Artystycznym”. Patrz: A. W i e r z b i c k a, Skorobohata-Stankiewicz Zofia, [w:] PSB, t. 38, s. 262-263. 
łecznych. Ogólną ciekawość wzbudziły prelekcje socjologa Kazimierza Krauza ${ }^{60}$, gromadzące dużą liczbę słuchaczy. Nie mniejszym powodzeniem cieszyły się wykłady Kazimierza Mokłowskiego, autora cennego dzieła Sztuka ludowa w Polsce, który ze znajomością przedmiotu zapoznał audytorium z dwutorowością dziejów polskiej sztuki ${ }^{61}$. Wystąpieniom towarzyszył pokaz zabytków budownictwa ludowego. Prelegent zorganizował wycieczki do chat góralskich, a nawet poza granice Zakopanego. W sferę sztuki wprowadził słuchaczy także Wilhelm Feldman'62. Z wielką subtelnością wniknął w twórczość dwóch „najpotężniejszych współczesnych autorów naszych" - Żeromskiego i Wyspiańskiego ${ }^{63}$.

Jedyne, co należało zmienić, to miejsce, w którym prowadzono trwające cztery do pięciu godzin wykłady - duszną, źle wentylowaną salę hotelu Morskie Oko. Natomiast odbywające się w poobiedniej porze konwersatoria pod gołym niebem posiadały odrębny, oryginalny charakter „i siła ich atrakcyjna zwycięsko walczy z czarami rozsłonecznionej, pysznej przyrody tatrzańskiej"64.

Prowadzone pod Giewontem Wyższe Kursy Wakacyjne, powstałe z inicjatywy młodych polskich sił naukowych, zwróciły uwagę „Biblioteki Warszawskiej”.

60 Kazimierz Kellles-Krauz (1872-1905); teoretyk i działacz PPS. Z wielkim zamiłowaniem prowadził działalność badawczo-naukową w zakresie socjologii. W swych pracach drukowanych w języku polskim, niemieckim i francuskim zajmował się teorią i historią socjologii, zwłaszcza teorią rozwoju idei i marksistowskiej teorii społeczeństwa, a także zagadnieniami etyki społecznej. Jego największym osiągnięciem w tej dziedzinie było sformułowanie tzw. prawa retrospekcji przewrotowej. Intensywna twórczość naukowa obejmowała też prawo pracy i teorię sztuki. Miał wykłady i odczyty w Paryżu, Brukseli i Krakowie (1902-1904); prowadził akcję oświatową w oddziale Uniwersytetu Ludowego im. A. Mickiewicza w Wiedniu, którego był założycielem i prezesem oraz w powstałym z jego inicjatywy Towarzystwie Wyższych Kursów Wakacyjnych. Patrz: W. B i e ń k o w s k i, Kelles-Krauz Kazimierz Radosław Elehard, [w:] PSB, t. 12, s. 328-332.

61 Kazimierz Mokłowski (1869-1905); dziennikarz i publicysta, architekt, historyk sztuki, działacz socjalistyczny. Za najbardziej powszechny do przyjęcia kanon piękna uznał treści artystyczne i ideowe, reprezentowane przez polską sztukę ludową, a w budownictwie styl zakopiański propagowany przez Stanisława Witkiewicza, do którego zbliżył się w Zakopanem (około 1900). Poza próbami zastosowania tego stylu do budownictwa mieszkaniowego, akcją popularyzatorską i odczytową, zakreślił sobie szerokie plany badawcze w zakresie genezy i rozwoju polskiej sztuki ludowej. Publikował m.in. na łamach „Biblioteki Warszawskiej”, „Prawdy”, „Słowa Polskiego”, Kwartalnika Historycznego”. Najważniejsze dzieło, Sztuka ludowa..., dowodziła wielkiej erudycji autora i ma trwałą wartość ze względu na zgromadzony materiał ikonograficzny (379 ilustracji). Kwestionowano natomiast wnioski wysuwane przez Mokłowskiego z dociekań etymologiczno-językowych. Patrz: W. B i e ń k o w s k i, Mokłowski Kazimierz, [w:] PSB, t. 21, s. 582-585.

62 Wilhelm Feldman (1869-1919); literat, historyk literatury i krytyk, polityk. W 1896 założył w Krakowie nowe pismo radykalno-postępowe „Dziennik Krakowski”, obejmujące swym zasięgiem wszystkie dzielnice Polski. W latach 1901-1914 redagował miesięcznik literacko-krytyczny i polityczno-społeczny „Krytyka”, wprowadzając szereg nowości w postaci nieznanych dotąd w czasopiśmiennictwie polskim ankiet, konkursów, dyskusji zbiorowych, a niekiedy ostrych polemik. Jego kolejne wielkie dzieło to Piśmiennictwo polskie ostatnich lat dwudziestu (Lwów 1902, t. 1-2), które już w roku następnym przerobione i rozszerzone objęło lata 1800-1901. Dokonał pierwszego syntetycznego ujęcia dorobku literacko-artystycznego Młodej Polski, opartego na zbadaniu olbrzymiego materiału polskiej i zagranicznej twórczości. Patrz: T. S. Grabowski, Feldman Wilhelm, [w:] PSB, t. 6 , s. $399-404$.

63 Z. S k o r o b o h a t a-S t r a n k i e w i c z, Zakopane, „Przegląd Tygodniowy” 1904, nr 36, s. 434.

64 Tamże. 
Pismo w dziale „Kronika miesięczna” pisało o efektach działalności podjętej przez popularyzatorów przedsięwzięcia:

[...] zapragnęli [...] zdobyć [...] placówkę i zdobyli ją. Zjechali na lato do Zakopanego, odbyli szereg wykładów i konserwatoryów, poruszyli umysły i, bądź co bądź, zjednali sobie powszechną sympatyę ${ }^{65}$.

Cel, w jakim zostały powołane wykłady - zachęcenie do nauki szerokich kół społecznych - był, w przekonaniu redakcji, niezwykle poważny. Stąd też zarząd kursów, korzystając z przychylnego nastawienia opinii publicznej, powinien dołożyć wszelkich starań, by spełniły one swe zadanie ${ }^{66}$.

Szczegółowy program wykładów Towarzystwa Wyższych Kursów Wakacyjnych w Zakopanem na drugi rok jego istnienia ogłosiła warszawska „Książka” miesięcznik poświęcony krytyce i bibliografii polskiej ${ }^{67}$. Redakcja poinformowała także o zmianach organizacyjnych. Liczba prelegentów wzrosła z 17 do 21 . Zamiast dwóch serii zaplanowano na rok 1905 trzy dwutygodniowe, z przynajmniej czterema dłuższymi (8-10 godzin) wykładami w każdej, dotyczącymi rozmaitych dziedzin wiedzy. Okres popołudniowy przewidziano na konwersatoria o charakterze swobodnych pogadanek. Podobnie jak przed rokiem, projektowano wycieczki naukowe: geologiczne, antropologiczne i folklorystyczne ${ }^{68}$.

Zapowiedź kursów wakacyjnych w Zakopanem na rok 1905 z zainteresowaniem witała także redakcja „Gazety Polskiej”. Przybliżając program wykładów, dziennik podkreślił, że wszystko „[...] jest bardzo ponętne i zachęcające [...]”. O wykładach wytworzyły się dwie opinie: wyrażająca uznanie i wdzięczność wobec prelegentów oraz zarzucająca, że nauka podawana była nie w czystej, wolnej od jakichkolwiek zabarwień formie, ale „załamywała się ustawicznie w pryzmacie poglądów partyjnych". Mimo kontrowersji, trudno było zaprzeczyć pożytkowi wynikającemu z przedsięwzięcia. Spory, jakie wywoływało, pobudzały ruch umysłowy w szerszych kręgach inteligencji69.

65 Kronika miesięczna, „Biblioteka Warszawska” 1904, t. 4, z. 1, s. 186.

66 Tamże, s. 187.

${ }^{67}$ M. E rn e s t, Fizyczna budowa słońca i planet; J. Ko d i s o w a, Irracjonalność pojęć jako źródło metafizyki; A. M a r h b u r g, Podstawy teorii nauki; W. N ałk o w s k i, Zasady geografii ogólnej jako wstęp do geografii Polski; L. S i l b e r s te i n, O falach elektro-magnetycznych; B. H ry n i e w i e cki, O życiu roślin w górach ze szczególnym uwzględnieniem roślinności tatrzańskiej; R. Minkiewicz, Czy darwinowska teoria doboru w walce o byt istotnie wyjaśnia ewolucję organiczną?; Z. H e ry n g, Logika ekonomii; W. J o d k o, Demokracja w nowoczesnym prawie państwowym; S. K a r p o w i c z, Zasady wykształcenia ogólnego; S. K o s z u t s k i, Życie ekonomiczne Królestwa Polskiego; K. K r a u z, Materializm historyczny; K. R a k o w s k i, Dzieje gospodarczego rozwoju Polski do końca XVIII wieku; J. J a k u b o w s k i, Dzieje Unii Litwy z Polską za Jagiellonów; L. K r z y w i c k i, Etnologia, folklor a historia w zastosowaniu do początków Polski; S. B r z o z o w s k i, O Zygmuncie Krasińskim; W. F eld ma n, Ibsen; A. K r y ń s k i, O rozwoju języka polskiego; B. Łe p k ij, O Tarasie Szewczence; H. M o n a t, O Juliuszu Słowackim; S. W i t k i e w i c z, Sztuka w życiu narodowym.

68 Kronika, „Książka” 1905, nr 7, s. 279.

69 Z.D., Z dnia na dzień, „Gazeta Polska” 1905, nr 119, s. 2. 
Przedstawiony w niniejszym artykule materiał prowadzi do następujących wniosków. Po pierwsze, tytułowe zagadnienie zaistniało na łamach pism warszawskich o różnorakim obliczu. Wskazać należy na organy o sprecyzowanym profilu („Książka”, „Świat”, „Wędrowiec”, „Wisła”). Zainteresowanie funkcjonowaniem oświaty w Zakopanem wyrażała również prasa naukowa („Biblioteka Warszawska"), periodyki popularnonaukowe, literackie, społeczne i artystyczne, przeznaczone dla szerszego kręgu odbiorców („Biesiada Literacka”, „Kronika Rodzinna”, „Przegląd Tygodniowy”, „Tygodnik Ilustrowany”, „Tygodnik Powszechny”) oraz kobiece („Bluszcz”, „Świt”). Głos we wskazanej kwestii zabrała także prasa codzienna („Gazeta Warszawska”, „Gazeta Polska”).

Zaprezentowane publikacje pozwalają stwierdzić, że prasę warszawską można - mimo istnienia granic zaborczych - traktować jako źródło do dziejów oświaty zakopiańskiej II połowy XIX i początków XX w. 